\title{
* BODIES OF WORK *
}

BODY, COMMODITY, TEXT

Studies of Objectifying Practice

A series edited by

ARJUN APPADURAI,

JEAN COMAROFF, and

JUDITH FARQUHAR 


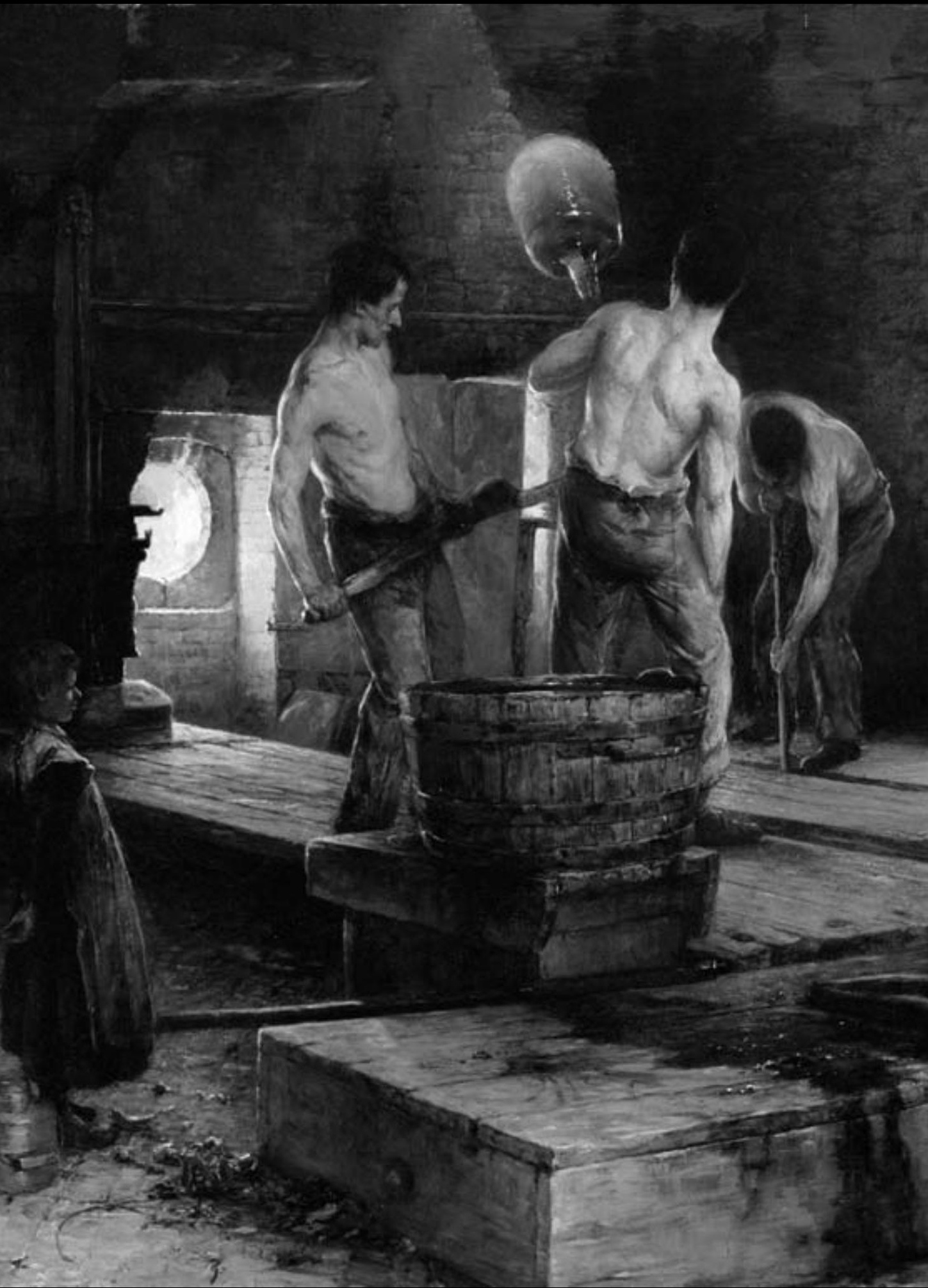




\section{EDWARD SLAVISHAK}

\section{* BODIES OF WORK *}

CIVIC DISPLAY AND LABOR IN

INDUSTRIAL PITTSBURGH 
(C) 2008 Duke University Press

All rights reserved

Printed in the United States of America

on acid-free paper $\infty$

Designed by C. H. Westmoreland

Typeset in Warnock Light by

Keystone Typesetting, Inc.

Library of Congress Cataloging-in-Publication

Data appear on the last printed

page of this book. 
TO MY MOTHER 
